\title{
BIOPSYCHOSOCIAL FACTORS AFFECTING HYPERTENSION IN POST-MENOPAUSAL WOMEN IN SURAKARTA, CENTRAL JAVA
}

\author{
Amalia Dinda Ayu Pradani1), Ambar Mudigdo²), Isna Qadrijati3) \\ ${ }^{1)}$ Masters Program in Public Health, Universitas Sebelas Maret \\ 2)Faculty Teaching and Educational Sciences, Universitas Sebelas Maret \\ 3)Faculty of Medicine, Universitas Sebelas Maret
}

\begin{abstract}
Background: Hypertension caused $45 \%$ mortality of heart disease and $51 \%$ mortality of stroke in 2014. Young women have a lower risk of hypertension than men. The risk increases after menopause due to lower estrogen production. This study aimed to estimate the biopsychosocial factors affecting hypertension in post-menopausal women in Surakarta, Central Java.

Subjects and Method: This was an analytic observational study with a crosssectional design. The study was conducted in Surakarta, Central Java, from January to February 2018. A sample of 200 study subjects was selected by fixed disease sampling. The dependent variable was hypertension. The independent variables were obesity, healthy diet, history of contraceptive use, family support, and family history of hypertension. Data of blood pressure was measured by sphygnomanometer. Other variables were measured by questionnaire. The data were analyzed by a multiple logistic regression.

Results: The risk of hypertension in post-menopuse women increased with obesity $(\mathrm{OR}=13.00 ; 95 \% \mathrm{CI}=2.99$ to $56.51 ; \mathrm{p}=0.001)$, family history of hypertension $(\mathrm{OR}=9.99 ; 95 \% \mathrm{CI}=2.54$ to $39.19 ; \mathrm{p}=0.001)$, and history of hormonal contraceptive use $(\mathrm{OR}=10.11 ; 95 \% \mathrm{CI}=2.60$ to $39.25 ; \mathrm{p}=0.001)$. The risk of hypertension in post-menopuse women decreased with healthy diet $(\mathrm{OR}=$ $0.16 ; 95 \% \mathrm{CI}=0.04$ to $0.55 ; \mathrm{p}=0.004)$ and strong family support $(\mathrm{OR}=0.09$; $95 \% \mathrm{CI}=0.19$ to $0.39 ; \mathrm{p}=0.001$ ).

Conclusion: The risk of hypertension in post-menopuse women is affected by obesity, family history of hypertension, history of hormonal contraceptive use, healthy diet, and strong family support.
\end{abstract}

Keywords: biopsychosocial, hypertension, post-menopause

\section{Correspondence:}

Amalia Dinda Ayu Pradani. Masters Program in Public Health, Universitas Sebelas Maret, Jl. Ir. Sutami 36 A, Surakarta 57126, Central Java.

Email: pradaniamalia@gmail.com. 